\title{
IMPROVE CUSTOMER SATISFACTION THROUGH DEMO OPEN KITCHEN IN SOCIAL MEDIA
}

\author{
Prasetya Tri Mahendra ${ }^{1}$ \\ Muhammad Bawono ${ }^{2}$ \\ Ulfa Aziza Umairoh ${ }^{3}$ \\ ${ }^{1}$ STIE Nganjuk \\ Email: prasetyatrimahendra@gmail.com \\ ${ }^{2}$ STIE Nganjuk \\ Email: muhammadbawono@stienganjuk.ac.id \\ ${ }^{3}$ STIE Nganjuk \\ Email: stienganjuk@stienganjuk.ac.id
}

\begin{abstract}
The purpose of this study was to determine and explain the use of demo open kitchen to consumer satisfaction through social media at HK Food Service Company, Nganjuk. In the last decade, demonstrations carried out do not have to be in front of consumers, but can be done in the form of video content that is recorded and then uploaded to social media. This type of research uses quantitative research methods with a causal associative research design. In determining the sample, researchers used 73 consumers. Analysis of the data used by using the validity test, reliability and classical assumption test. Hypothesis testing is done by performing t statistical tests, with data collection techniques in the form of online questionnaires. Hypothesis testing by doing t statistical test with the results of the study concluded that the demo open kitchen has a partial effect on customer satisfaction, as evidenced by the acquisition of the $t$ value is greater than $t$ table with a significance of less than 0.05 . Besides that, it turns out that social media is a medium for socializing with each other and is done online which allows humans to interact with each other without being limited by space and time.
\end{abstract}

Keywords : Demo Open Kitchen, social media, consumer satisfaction

\section{INTRODUCTION}

The era of globalization has hit all aspects of life, especially aspects of marketing management. In the business world, marketing has a very important role. Consumer satisfaction is the level of consumer feelings after comparing what is received and what is expected, by demonstrating how to cook is an activity to show the general public, demonstration experiments in the manufacture of a product with processed ingredients will increase consumer confidence in the product it consumes.

Tight business competition as it is today makes business people always try to maintain their business and compete to achieve the expected goals. Business people always expect growth which always increases from time to time. Along with the development of advances in science and technology. Society in general will make decisions that are practical, flexible, and efficient. The dynamic behavior of modern society makes an entrepreneur responsive to changes in the existing environment to make the business run grow. People with routine activities outside the home are sometimes unable to meet their needs to maintain their body condition (food and drink), and tend to use the services of other parties (food stalls, restaurants, and food service companies). Even then, they use social media facilities in their information and transactions, so it takes expertise for service marketers to create content / cooking demo videos for the food they sell. From the video, consumers can find out the process of cooking, ingredients (nutritional and halal content) / demonstration, as well as the hygiene / health factors of the ingredients being cooked.

One aspect that is no less important in keeping consumers satisfied is trust. This statement is reinforced by experts who state that trust is an important element in consumer satisfaction, trust is an important basis for building and maintaining long-term relationships (Akbar \& Parvez, 2009). Several previous researchers, namely (Sukarmen et al., 2015), (Yulistira, 2017), (Lenzun et al., 2014) only use price, promotion, and product innovation as a basis for increasing consumer satisfaction, and even then with the usual marketing methods. Whereas in this study, the researcher will bring up an open demo kitchen (open promotional demo) which is conducted online through social media so that the level of trust and customer satisfaction can be increased with simpler means and methods but can have a wider influence than the usual marketing methods. The purpose 
of this research is to find out and explain the use of open kitchen demo to consumer satisfaction through social media which is beneficial for the development and marketing knowledge in the digital era 4.0.

By looking at the business opportunities and the rapid growth of the culinary business, the HK food service company was chosen as the object of this research which uses social media as a means of marketing its products.

\section{THE PROBLEM}

How is the effect of using an open demo kitchen through social media in increasing consumer satisfaction?

\section{THEORETICAL STUDY Open Kitchen Demo}

Demo Open kitchen or demonstrate how to cook is an activity to show the general public, a demonstration experiment in making a product with processed ingredients (Wati \& Rakhmawati, 2016). For example, a street vendor fried rice seller who in the manufacturing process always shows / demonstrates how to cook to the buyer. In the last decade, demonstrations carried out do not have to be directly in front of consumers, but can be done in the form of video content that is recorded and then uploaded to social media, for example YouTube, Instagram, Facebook or others.

\section{Customer Satisfaction}

Consumer satisfaction is defined by (Kotler \& Keller, 2016), which states that: "Satisfaction is a person's feelings of pleasure or disappointment that result from comparing a product or service's perceived performance (or outcome) to expectations". Consumers can experience one of three levels of general satisfaction, namely if the performance is below expectations, consumers will feel disappointed but if the performance is in accordance with customer expectations will feel satisfied and if the performance can exceed expectations, the customer will feel very satisfied, happy or happy.

According to (Husein Umar, 2013) "Consumer satisfaction is the level of consumer feelings after comparing what is received and what is expected." In addition, according to (Tjiptono \& Fandy, 2015) defines "consumer satisfaction is an emotional response to experiences related to certain products or services purchased, retail outlets, or even behavioral patterns (such as shopping behavior and buyer behavior), as well as market behavior. whole. Emotional responses are triggered by a cognitive evaluation process that compares perceptions (or beliefs) of certain objects, actions or conditions with individual values (or needs, wants and desires).

Based on some of the definitions of customer satisfaction above, it can be concluded that customer satisfaction concerns the components of expectation satisfaction (expectations and perceived performance / results). More specifically, customer satisfaction means the extent to which the perceived quality of the product meets customer expectations.

\section{Social Media}

Social media is a collection of internet-based applications, based on Web ideology and technology to enable the creation and exchange of content by its users (Kaplan \& Haenlein, 2016), while according to (Rafi Saumi Rustian, 2012) Social media is a medium for socializing with each other and done online which allows humans to interact with each other without being limited by space and time.

\section{Marketing}

According to (Kotler \& Armstrong, 2018) defines marketing, namely Marketing as the process by which companies create value for customers and build strong customer relationships in order to capture value from customers in return, which means that marketing is a process where companies create value for customers and build relationships. customers to capture value from customers in return.

Another case with the formal definition offered by the America Marketing Association (AMA) cited by (Kotler \& Keller, 2016), namely Marketing is the activity, set of institutions, and processes for creating, communicating, delivering, and exchanging offerings that have value for customers, clients, partners, and society at large. which means Marketing is an organizational function and a series of processes to create, communicate, deliver, and deliver superior customer value. 


\section{Marketing Management}

According to (Kotler \& Armstrong, 2018) defines marketing management, namely "Marketing management as the art and science of choosing target markets and building profitable relationships with them," which means marketing management is the art and science of choosing target markets and building profitable relationships with them. Equipped with an expression (Kotler \& Keller, 2016) which says that marketing management is "Marketing management as the art and science of choosing target markets and getting, keeping, and growing customers through creating, delivering, and communicating superior customer value," which means Marketing management as the art and science of selecting target markets and acquiring, retaining and increasing the number of customers by creating, delivering and communicating superior customer value.

According to (Alma, 2014) "marketing management is the activity of analyzing, planning, implementing and supervising all activities in order to achieve the marketing level in accordance with the goals set by the company." Based on several definitions put forward by experts, researchers can understand that marketing management is a science that can be applied in an organization, company or individually in maintaining the survival of the organization through beneficial exchanges with the process of planning, implementing, coordinating and controlling programs involves the concept of marketing.

So that as a whole it can be connected that consumer satisfaction is an important thing in the marketing of goods / services, through direct cooking demonstrations will increase consumer confidence / satisfaction with the food they consume and this can be done through social media for wider, cheaper and easier marketing.

\section{RESEARCH METHOD}

This type of research in research is quantitative research with a causal associative research design. The quantitative approach is used to examine the symptoms of a specific population or sample by using research instruments as statistical data collection in order to test predetermined hypotheses.

\section{Population and Sample}

Population is an object / subject that is in one area and fulfills certain requirements related to research problems. In this study, the population is all consumers of Catering HK Nganjuk totaling 357 people. The determination of the number of the sample of researchers is in accordance with the opinion (Arikunto, 2010), which states that "if the subject is less than 100 people, all of them should be taken, if the subject is large or more than 100 people can be taken $10-15 \%$ or 20 - $25 \%$ or more." Based on this opinion, the sample of this study was determined to be $20 \%$ of the total population so that the sample size was $20 \%$ x 357, so the number of samples was 73 people. For the sampling technique, researchers used a purposive sampling technique. According to (Sugiyono, 2015) "The sampling technique in research is using non-probability sampling techniques with judgment sampling method (purposive sampling) or sampling technique with certain considerations. The considerations used are consumers who purchase products at least 2 times at Catering HK Nganjuk.

\section{Research Variables \\ Independent Variable}

The independent variable is the Open Kitchen Demo, which is a cooking method / process demo recorded in a video with a certain duration which is then uploaded to social media (Youtube, Instagram, and Facebook).

\section{Dependent Variable}

The dependent variable is the level of consumer satisfaction $(\mathrm{Y})$, which is how satisfied the consumer is with the food he ordered, how many times have ordered and informed friends / relatives to join in the order or just want to know the process of making it, so that he is more confident about the goods / food he has bought.

\section{Operational Definition}

Operational definition is a definition of a variable that is formulated based on the characteristics of the observed variable. The operational definition has a single meaning and is 
objectively accepted, when the variables appear (Huda, 2018). The operational definition of this research is:

1. Open Kitchen Demo, variable $X$, is an activity to demonstrate the cooking process, starting from ingredients, spices, equipment and processing, which usually means that if we want to buy food and then know the processing process, we will be more confident in buying and consuming it. However, this activity was videotaped and uploaded on social media accounts. Meanwhile, Demonstration is an activity to show the general public, a demonstration experiment in making a product (Alma, 2018).

2. Consumer Satisfaction, variable $\mathrm{Y}$, is a positive assessment from consumers of the product or service they buy. (Tjiptono \& Fandy, 2015) defines "consumer satisfaction is an emotional response to experiences related to certain products or services purchased, retail outlets, or even behavior patterns (such as shopping behavior and buyer behavior), as well as the market as a whole.

The instrument used in this study is expected to provide accurate results, then the Likert scale is used, which is a scale used to measure the attitudes, opinions and perceptions of a person or group of people about a social phenomenon (Sugiyono, 2015). In this study, researchers used a questionnaire / questionnaire instrument with the following scores:

$\begin{array}{lll}\text { SS } & =\text { Strongly Agree } & : 5 \\ \mathrm{~S} & =\text { Agree } & : 4 \\ \mathrm{~N} & =\text { Neutral } & : 3 \\ \mathrm{TS} & =\text { Disagree } & : 2 \\ \text { STS } & =\text { Strongly Disagree: } 1\end{array}$

Data analysis using validity, reliability and classical assumption tests. Hypothesis testing by performing $t$ statistical test for partial testing. Then the researchers compiled a blueprint for the scale of the instrument containing indicators about the open demo kitchen and consumer satisfaction, which consisted of favorable and unfavorable statements.

Table 1

Blue Print Instrument Scale of Demo Open Kitchen (X)

\begin{tabular}{|l|l|l|c|c|c|}
\hline No. & \multicolumn{1}{|c|}{ Aspect } & \multicolumn{1}{c|}{ Indicators } & Favorable & Unfavorable & Amount \\
\hline 1 & Demonstration & $\begin{array}{l}\text { Become a means of } \\
\text { communication for the } \\
\text { general public }\end{array}$ & $2,7,18,20,24,27$ & 19,26 & $\mathbf{8}$ \\
\hline 2 & $\begin{array}{l}\text { Materials and } \\
\text { Results }\end{array}$ & $\begin{array}{l}\text { Shows the advantages of } \\
\text { the product }\end{array}$ & $1,3,4,13,17,25$ & $5,8,10$ & $\mathbf{9}$ \\
\hline 3 & Information & $\begin{array}{l}\text { Invite consumers to be } \\
\text { able to share information }\end{array}$ & $6,9,12,15$ & 13,16 & $\mathbf{6}$ \\
\hline 4 & Marketing & Attract consumers & $11,14,21$ & 22,23 & $\mathbf{5}$ \\
\hline & & & $\mathbf{1 9}$ & $\mathbf{9}$ & $\mathbf{2 8}$ \\
\hline
\end{tabular}

Table 2

Blue Print Instrument Scale of Consumer Satisfaction (Y)

\begin{tabular}{|l|l|l|c|c|c|}
\hline No. & \multicolumn{1}{|c|}{ Aspect } & \multicolumn{1}{c|}{ Indicators } & Favorable & Unfavorable & Amount \\
\hline 1 & Service & $\begin{array}{l}\text { The services provided are } \\
\text { in accordance with } \\
\text { consumer expectations }\end{array}$ & $8,15,21,25,27,28$ & $22,23,26$ & $\mathbf{8}$ \\
\hline 2 & Selection & $\begin{array}{l}\text { Becoming a consumer of } \\
\text { HK Catering Services is } \\
\text { the right choice consumers }\end{array}$ & $2,7,10,11$ & $3,13,16$, & $\mathbf{7}$ \\
\hline 3 & Commitment & $\begin{array}{l}\text { will come back to become } \\
\text { customers }\end{array}$ & $1,6,12,13,21$ & 5,19 & $\mathbf{7}$ \\
\hline 4 & Promotion & $\begin{array}{l}\text { Consumers are willing to } \\
\text { recommend services } \\
\text { provided to others }\end{array}$ & $4,, 9,14,17,18$ & 20 & $\mathbf{6}$ \\
\hline & & $\mathbf{1 9}$ & $\mathbf{9}$ & $\mathbf{2 8}$ \\
\hline
\end{tabular}




\section{RESEARCH RESULTS}

\section{Frequency Distribution of Respondents}

Based on the research data that has been collected, data is obtained about the demographics of the research respondents consisting of: (1) age, (2) gender, (3) latest education (4) the following number of purchases:

Table 3

Characteristics by Age

\begin{tabular}{|c|l|c|c|}
\hline No. & \multicolumn{1}{|c|}{ Characteristics } & Frequency & Percentage (\%) \\
\hline 1 & 15-20 years & 12 & $16,44 \%$ \\
\hline 2 & $21-30$ years & 39 & $53,42 \%$ \\
\hline 3 & $31-40$ years & 20 & $27,40 \%$ \\
\hline 4 & Over 41 Years & 2 & $2,74 \%$ \\
\hline & Amount & $\mathbf{7 3}$ & $\mathbf{1 0 0 , 0 0 \%}$ \\
\hline
\end{tabular}

Table 3 shows in terms of age, of the 73 consumers of HK Catering Services, Nganjuk who became respondents in this study were dominated by the 21-30 year age group, namely 39 people or $53.42 \%$ of respondents, there were 20 people or $27.40 \%$ of respondents. aged $31-40$ years, there were 12 people or $16.44 \%$ of respondents aged 15-20 years and the rest were at least 2 people aged over 41 years or $2.74 \%$ of respondents.

Table 4

Characteristics Based on Gender

\begin{tabular}{|c|l|c|c|}
\hline No. & \multicolumn{1}{|c|}{ Characteristics } & Frequency & Percentage (\%) \\
\hline 1 & Male & 4 & $5,48 \%$ \\
\hline 2 & Female & 69 & $94,52 \%$ \\
\hline & Amount & $\mathbf{7 3}$ & $\mathbf{1 0 0 , 0 0 \%}$ \\
\hline
\end{tabular}

Table 4 shows in terms of gender, out of 73 consumers of HK Catering Services, Nganjuk who were respondents in this study were dominated by female customers, namely 69 women or $94.52 \%$ of respondents, while only 4 men or $5.48 \%$ of respondents.

Table 5

Characteristics Based on Recent Education

\begin{tabular}{|c|l|c|c|}
\hline No. & \multicolumn{1}{|c|}{ Characteristics } & Frequency & Percentage (\%) \\
\hline 1 & $\begin{array}{l}\text { Completed Junior High } \\
\text { School / equivalent }\end{array}$ & 6 & $8,22 \%$ \\
\hline 2 & $\begin{array}{l}\text { Completed high school / } \\
\text { equivalent }\end{array}$ & 28 & $38,36 \%$ \\
\hline 3 & $\begin{array}{l}\text { Completed Undergraduate } \\
\text { (Bachelor) }\end{array}$ & 39 & $53,42 \%$ \\
\hline & Amount & $\mathbf{7 3}$ & $\mathbf{1 0 0 , 0 0 \%}$ \\
\hline
\end{tabular}

Table 5 shows the characteristics based on the latest education, out of 73 consumers of HK Catering Services, Nganjuk who were respondents in this study were dominated by consumers with the latest education of Completed Undergraduate (Bachelor) as many as 39 people or $53.42 \%$ of respondents, there were 28 people or $38,36 \%$ of respondents with the latest education are High School / equivalent, and there are 6 people or $8.22 \%$ of respondents with the latest education is Junior High School / equivalent. 
Table 6

Characteristics Based on Purchase Amount

\begin{tabular}{|c|l|c|c|}
\hline No. & \multicolumn{1}{|c|}{ Characteristics } & Frequency & Percentage (\%) \\
\hline 1 & $1-5$ times & 5 & $6,85 \%$ \\
\hline 2 & $6-10$ times & 41 & $56,16 \%$ \\
\hline 3 & $11-15$ times & 25 & $34,25 \%$ \\
\hline 4 & More than 16 times & 2 & $2,74 \%$ \\
\hline & Amount & $\mathbf{7 3}$ & $\mathbf{1 0 0 , 0 0 \%}$ \\
\hline
\end{tabular}

Table 6 shows the characteristics based on the number of consumer purchases, of the 73 consumers of HK Catering Services, Nganjuk who were respondents in this study as many as 41 people or $56.16 \%$ of respondents had made purchases 6-10 times, there were 25 people or $34.25 \%$. respondents have made purchases 11 - 15 times, there are 5 people or $6.85 \%$ of respondents have made purchases 1 - 5 times and there are 2 people or $2.74 \%$ of respondents have made purchases more than 16 times.

\section{Validity and Reliability Test Validity Test Results}

The validity test is useful for determining the feasibility of the questions posed in the questionnaire. This test is conducted to measure the data that has been obtained, whether the questions raised in the questionnaire are able to answer the research questions. The validity test in this study was carried out with the SPSS program. According to (Sugiyono, 2015) "Items that have a positive correlation with the criterion (total score) and high correlation, indicate that these items have high validity as well. The significance test is done by comparing the calculated $r$ value with the $\mathrm{r}$ table for degree of freedom $(\mathrm{df})=\mathrm{n}-2$, in this case $\mathrm{n}$ is the number of samples. In testing the validity of this study, the researcher conducted this study on 73 respondents. So the df used is 73$2=71$ with an alpha of $5 \%$, it produces a value of $r$ table (two-sided test) of 0.230 provided that if $r$ count $\geq r$ table, it means that the correlation of statement items meets the tolerance requirements for the total score, then declared valid. The following are the results of the validity test in this study.

Table 7

Validity Test Results

\begin{tabular}{|c|c|c|c|c|}
\hline Variable & Instrument Item & r value & r table & Description \\
\hline \multirow{4}{*}{ Demo Open Kitchen (X) } & Statement 1 & 0,830 & 0,230 & Valid \\
\cline { 2 - 5 } & Statement 2 & 0,660 & 0,230 & Valid \\
\cline { 2 - 5 } & Statement 3 & 0,812 & 0,230 & Valid \\
\cline { 2 - 5 } & Statement 4 & 0,800 & 0,230 & Valid \\
\hline \multirow{4}{*}{ Customer Satisfaction (Y) } & Statement 1 & 0,764 & 0,230 & Valid \\
\cline { 2 - 5 } & Statement 2 & 0,772 & 0,230 & Valid \\
\cline { 2 - 5 } & Statement 3 & 0,667 & 0,230 & Valid \\
\cline { 2 - 5 } & Statement 4 & 0,831 & 0,230 & Valid \\
\hline
\end{tabular}

Based on table 7 above regarding the validity test, it is known that the value of $r$ count of statement items on all variables in this study has a value of $r$ value $\geq r$ table, so the statement items from the questionnaire can be said to be valid.

\section{Reliability Test Results}

Reliability test is useful to see whether the research instrument (in this case the questionnaire) is a reliable and trustworthy instrument. A variable is said to be reliable if it gives a Cronbach's Alpha value greater than 0.6 and vice versa if the Cronbach's Alpha value is smaller than 0.6 then the questionnaire is not reliable. The following are the results of the reliability test. 
Table 8

Reliability Test Results

\begin{tabular}{|c|c|c|c|}
\hline Variable & Cornbach alpha & Limit & Description \\
\hline Demo Open Kitchen $(\mathrm{X})$ & 0,781 & 0,60 & Reliabel \\
\hline Customer Satisfaction $(\mathrm{Y})$ & 0,742 & 0,60 & Reliabel \\
\hline & & & \\
\hline
\end{tabular}

Based on table 8 above regarding the reliability test, it can be seen that the lowest Cornbach alpha value is 0.742 and the highest is 0.781 . This shows that all Cornbach alpha values are greater than 0.60. This means that all variables are declared reliable.

\section{Classical Assumption Test Results \\ Normality Test}

The purpose of data in the normality test is to test whether in the regression model, the distribution of a data follows or approaches the normal distribution or not. In linear regression models, this assumption is indicated by the error value that is normally distributed. A good regression model is a regression model that has a normal or near-normal distribution, so it is feasible to do statistical testing. Data normality testing used the Kolmogorov-Smirnov Test of Normality in the SPSS program. According to (Santoso, 2012) the basis for decision making can be made based on probability (Asymtotic Significance), namely: if the probability $\geq 0.05$ then the distribution of the data is normal, whereas if the probability $<0.05$ then the distribution of the data is not normal.

Table 9

The Frequency of Normality Test Results

One-Sample Kolmogorov-Smirnov

Test

\begin{tabular}{|ll|r|}
\hline & $\begin{array}{r}\text { Unstandar } \\
\text { dized } \\
\text { Residual }\end{array}$ \\
\hline$N$ & & 73 \\
Normal & Mean & .0000000 \\
Paramete & Std. & 1.1749758 \\
rs a,b & Deviation & 1 \\
Most & Absolute & .098 \\
Extreme & Positive & .054 \\
Differenc & Negative & -.098 \\
es & & \\
Kolmogorov-Smirnov & .833 \\
Z & \\
Asymp. Sig. (2-tailed) & .491 \\
\hline \multicolumn{2}{|c|}{ a. Test distribution is Normal. } \\
b. Calculated from data.
\end{tabular}

Based on table 9 above regarding the normality test (Kolmogorov-Smirnov) obtained by Asymp. Sig. (2-tailed) of 0.491. This indicates that the Asymp. Sig. (2-tailed) KolmogorovSmirnov $\mathrm{Z}$ is greater than $0.05(0.491 \geq 0.05$, so this proves that in this study the residual data has been normally distributed, so that further testing can be carried out).

\section{Heteroscedasticity Test}

The heteroscedasticity test aims to test whether in the regression model there is an inequality of variance from the residuals of one observation to another, if the residual variance from one observation to another is different it is called heteroscedasticity. The detection was carried out using the Glejser test method. The Glejser test is by regressing all independent variables to their absolute residual values. The basis for decision making does not occur heteroscedasticity, if the significance value $>0.05$ while heteroscedasticity occurs, the significance value $<0.05$ 
Table 10

Heteroscedasticity Test Results

\begin{tabular}{|c|c|c|}
\hline Variable & $\begin{array}{c}\text { Heteroscedasticity } \\
\text { Test Results }\end{array}$ & Significant Level \\
\hline Demo Open Kitchen $(\mathrm{X})$ & 0,766 & 0,446 \\
\hline
\end{tabular}

Based on Table 10 the heteroscedasticity test above, it can be seen that the value of the Demo Open Kitchen $(\mathrm{X})$ variable has a significance of 0.446 . This shows that all the independent variables in this study, namely the online Open Kitchen Demo, are more than the significance value of 0.05 . So for this test heteroscedasticity does not occur.

\section{Hypothesis Testing \\ Significance Test of Individual Parameters (t Statistical Test)}

This test is conducted to determine whether the independent variables partially have a significant effect on the dependent variable. By using a significant level $(\alpha)$ of $5 \%$ or 0.05 if $t$ count $>\mathrm{t}$ table and the significance is less than 0.05 , the hypothesis is accepted, meaning that there is a significant influence between the independent variables on the dependent variable. The calculated $t$ value can also be compared with the $t$ table value. The decision making criteria are:

Table 11

Partial Significance Test Results (t-test)

Coefficients $^{a}$

\begin{tabular}{|c|c|c|c|c|c|}
\hline \multirow[t]{2}{*}{ Model } & \multicolumn{2}{|c|}{$\begin{array}{l}\text { Unstandardi } \\
\text { zed } \\
\text { Coefficients }\end{array}$} & $\begin{array}{c}\text { Standardized } \\
\text { Coefficients }\end{array}$ & \multirow[b]{2}{*}{$t$} & \multirow[b]{2}{*}{ Sig. } \\
\hline & $B$ & $\begin{array}{c}\text { Std. } \\
\text { Error }\end{array}$ & & & \\
\hline 1 (Constant) & .636 & .905 & & .703 & .484 \\
\hline$X 1$ & .209 & .082 & .217 & 2.558 & .013 \\
\hline
\end{tabular}

a. Dependent Variable: $Y$

Based on table 11 above, the $t$ test (partial) can be seen for determining the $t$ table value. where the level of significance $(\alpha)=0.05(5 \%)$ and degrees of freedom $(\mathrm{df})=(\mathrm{n}-\mathrm{k})$ or $(73-2=$ 71 ), so that the df value is 71 , then the $t$ table value is 1.666 . Thus, partial testing can be carried out as follows:

Open Kitchen demo to customer satisfaction

The second partial hypothesis in this study can be formulated as follows:

H0: $\beta 2=0$, meaning that Open Kitchen Demo has no partial effect on customer satisfaction Ha: $\beta 2 \neq 0$, meaning that the Open Kitchen Demo has a partial effect on customer satisfaction It is known that the $t$ value of the open demonstration variable $(\mathrm{X})$ is 2.558 with a significance of 0.013 . This shows that the $t$ value is greater than $t$ table $(2.558>1.666)$ and the significance is less than $0.05(0.013<0.05)$, then $\mathrm{Ha}$ is accepted and $\mathrm{H} 0$ is rejected, meaning that the second hypothesis which states that Demo Open Kitchen has an effect partial to customer satisfaction is acceptable.

\section{DISCUSSION}

Based on this discussion, it is known the importance of open demo kitchens in consumer satisfaction through social media. Applications that have been done are Facebook, WhatsApp, and Instagram.

The results of the partial test conducted in this study, it aims to identify and analyze demo open kitchen on customer satisfaction at UD. Catering Humaira Kitchen in Balongrejo Village, Berbek District, Nganjuk Regency can be explained as follows: 


\section{Effect of Open Kitchen Demo on customer satisfaction}

Based on the partial significance test (t-test), it shows that the Open Kitchen Demo variable is positive. This positive value shows that the influence of the Open Kitchen Demo which consists of: demonstration activities being a means of communication with the general public, is carried out to show the advantages of the products offered, can invite consumers to gather and exchange information and can attract consumer interest, so that if the Open Kitchen Demo is increasingly repaired and improved, then consumer satisfaction will be high and vice versa. This means that the Open Kitchen Demo has a partial effect on customer satisfaction. In accordance with the opinion (Kotler \& Keller, 2016), that demonstration is a promotional tool which is a demonstration that is done to show or prove the effectiveness or how to use the product.

This study contrasts with research (Lenzun et al., 2014) entitled The Effect of Product Quality, Price and Promotion on Customer Satisfaction of Telkomsel Prepaid Cards which concludes that promotion has a negative but not significant effect on customer satisfaction. This research is in line with research (Sukarmen et al., 2015) with the title Analysis of the Effect of Product Innovation on Consumer Satisfaction with Competitive Advantage as an Intervening Variable in Eleven Sugar Products (Gupalas) PTP Nusantara XI (Persero) 's Semboro Sugar Factory which concluded that product innovation effect on Competitive Advantage. This statement supports the opinion of (Kotler \& Keller, 2016) which states that relative profit is the level at which innovation looks better than old products. The level of excess of an innovation, is it better than previous innovations or things that are usually done, so that it has an impact on customer satisfaction.

\section{CONCLUSIONS}

Demo Open Kitchen has an effect on increasing consumer satisfaction at Catering Services Company HK, Nganjuk. It is proven by the acquisition of the $t$ value is greater than $t$ table with a significance of less than 0.05 .

\section{SUGGESTIONS}

1. Open Kitchen Demo HK Food Service Company, Nganjuk still needs to pay attention to marketing models through other social media by creating promotional / content facilities that can attract consumer interest.

2. Expanding the scope of research, increasing the number of samples and selecting random samples, so that research results can be generalized and can contribute to increasing the accuracy of research results and can develop existing models by adding variables that affect customer satisfaction.

\section{REFERENCES}

Akbar, M. M., \& Parvez, N. (2009). IMPACT OF SERVICE QUALITY , TRUST , AND CUSTOMER Mohammad Muzahid Akbar and Noorjahan Parvez. ABAC Journal.

Alma, B. (2014). Promosi. Manajemen Pemasaran Dan Pemasaran Jasa. https://doi.org/10.1017/CBO9781107415324.004

Alma, B. (2018). Pemasaran dan Pemasaran Jasa. In Pemasaran dan Pemasaran Jasa.

Arikunto, S. (2010). Prosedur Penelitian Ilmiah. In Rineka cipta, Jakarta.

Huda, F. A. (2018). Pengertian Definisi Operasional. 26 Maret.

Husein Umar. (2013). Husein Umar, Riset Pemasaran dan Perilaku Konsumen, 2004. Journal of Chemical Information and Modeling. https://doi.org/10.1017/CBO9781107415324.004

Kaplan, A. M., \& Haenlein, M. (2016). Higher education and the digital revolution: About MOOCs, SPOCs, social media, and the Cookie Monster. Business Horizons. https://doi.org/10.1016/j.bushor.2016.03.008

Kotler, P., \& Armstrong, G. (2018). Principle of Marketing. In Principles of Marketing.

Kotler, P., \& Keller, K. L. (2016). Marketing Mangement. In Pearson Edition Limited. 
Lenzun, J. J., Massie, J. D. ., \& Adare, D. (2014). Pengaruh Kualitas Produk, Harga dan Promosi terhadap Kepuasan Pelanggan Kartu Prabayar Telkomsel. Jurnal EMBA. https://doi.org/10.1109/25.765000

Rafi Saumi Rustian. (2012). Apa itu Sosial Media. In 01 Maret 2012.

Santoso, S. (2012). Statistik Parametrik. Statmat : Jurnal Statistika Dan Matematika. https://doi.org/10.32493/sm.v1i1.2377

Sugiyono. (2015). Metode Penelitian. Metode Penelitian.

Sukarmen, P., Sularso, A., \& Wulandari, D. (2015). Analisis Pengaruh Inovasi Produk Terhadap Kepuasan Konsumen Dengan Keunggulan Bersaing Sebagai Variabel Intervening Pada Produk Gula Pasir Sebelas (Gupalas) Pabrik Gula Semboro Ptp Nusantara XI (Persero). Jurnal Ekonomi Akuntansi Dan Manajemen.

Tjiptono, \& Fandy. (2015). Strategi Pemasaran, edisi keempat. In Edisi I. Yogyakarta: Andi.

Wati, U. K., \& Rakhmawati, E. (2016). MENINGKATKAN MOTORIK HALUS MELALUI KEGIATAN MEMASAK PADA SISWA KELOMPOK B TK KARTIKA III-41 DEMAK TAHUN AJARAN 2015 / 2016. PAUDIA : JURNAL PENELITIAN DALAM BIDANG PENDIDIKAN ANAK USIA DINI. https://doi.org/10.26877/paudia.v5i1.1176

Yulistira, S. (2017). Pengaruh Price Discount, Bonus Pack, Dan In-Store Display Terhadap Impulse Buying Serta Pengaruhnya Pada Kepuasan Konsumen (Studi Pada Supermarket Xing Mart di Kota Pontianak). 